\title{
The Effect of Herbage Allowance and Concentrate Supplementation on Milk Production Performance and Dry Matter Intake of Spring-Calving Dairy Cows in Early Lactation
}

\author{
M. McEvoy, ${ }^{*} \dagger^{1}$ E. Kennedy, ${ }^{*}$ J. P. Murphy, ${ }^{*}$ T. M. Boland, $\dagger$ L. Delaby, $\ddagger$ and M. O’Donovan* \\ *Dairy Production Research Centre, Teagasc, Moorepark, Fermoy, Co. Cork, Ireland \\ †School of Agriculture, Food Science and Veterinary Medicine, UCD, Belfield, Dublin, Ireland \\ ‡Institut National de la Recherche Agronomique, Unité Mixte de Recherche, Production du Lait, St Gilles, France
}

\begin{abstract}
The objective of this study was to determine the effect of daily herbage allowance (DHA) and concentrate level on milk production and dry matter intake of springcalving dairy cows in early lactation. Seventy-two Holstein-Friesian dairy cows (mean calving date February 2 ) were randomly assigned across 6 treatments $(n=12)$ in a $2 \times 3$ factorial arrangement. The 6 treatments consisted of 2 DHA $(>4 \mathrm{~cm})$ and 3 concentrate levels: $13 \mathrm{~kg}$ of herbage dry matter/cow per d (low) or $17 \mathrm{~kg}$ of herbage dry matter/cow per d (high) DHA and unsupplemented, $3 \mathrm{~kg}$, or $6 \mathrm{~kg}$ of dry matter concentrate/cow per $\mathrm{d}$. The experimental period (period I) lasted $77 \mathrm{~d}$ and was followed by a carryover period (period II) during which animals were randomly reassigned across 2 grazing treatments offering 17 or $21 \mathrm{~kg}$ of herbage dry matter/cow per d. Increasing DHA significantly increased milk $(+1.85 \mathrm{~kg})$, solids-corrected milk, protein $(+79.5 \mathrm{~g})$, and lactose yields, protein concentration, and mean body weight (BW). Mean body condition score (BCS) and end-point BCS were also significantly higher with the high-DHA treatments. There was a linear response in milk yield, milk lactose concentration, and solids-corrected milk to concentrate supplementation. There was a significant difference in mean BW as concentrate increased from 0 to $3 \mathrm{~kg}$ ( 506 and $524 \mathrm{~kg}$, respectively); there was no further increase in $\mathrm{BW}$ when $6 \mathrm{~kg}$ of concentrate was offered. Cows offered the low DHA had significantly lower grass dry matter intake $(13.3 \mathrm{~kg})$ and total dry matter intake $(16.3 \mathrm{~kg})$ than the high-DHA cows during period I. Concentrate supplementation significantly increased total dry matter intake. During period II, previous DHA continued to have a significant carryover effect on milk protein concentration, BW change, mean BCS, and end-point BCS. Con-
\end{abstract}

Received September 20, 2007.

Accepted November 19, 2007.

${ }^{1}$ Corresponding author: mary.mcevoy@teagasc.ie centrate supplementation during period I continued to have a significant carryover effect in period II on milk yield; milk fat, protein, and lactose yields; solids-corrected milk yield; BW; and mean BCS. Results from this study indicate that offering a medium level of DHA (17 kg of herbage dry matter) in early lactation will increase milk production. Offering concentrate will result in a linear increase in milk production. In an early spring feed-budgeting scenario, when grass supply is in deficit, offering $3 \mathrm{~kg}$ of dry matter concentrate with $17 \mathrm{~kg}$ of DHA has the additive effect of maintaining the grazing rotation at the target length as well as ensuring the herd is adequately fed.

Key words: herbage allowance, concentrate supplementation, milk production, dairy cow

\section{INTRODUCTION}

Rising production costs and falling farm gate product prices have induced a transformation of grassland management practices over the past decade. With future feed costs projected to increase, using more grass in the diet of the lactating cow is a major objective for the Irish dairy industry. Dillon et al. (2005) has shown that a $10 \%$ increase in the proportion of grazed grass in the feeding system will reduce the cost of milk produced by 2.5 cents/L. As well as improving the economics of the farm enterprise, replacing grass silage with grazed grass in the diet of spring-calving dairy cows in early lactation has been shown to increase milk production (Dillon et al., 2002) and milk protein concentration (Kennedy et al., 2005). Targeting the early-lactation period for this increased grass input may eliminate the requirement to offer grass silage to animals in early lactation. Depending on the daily herbage allowance (DHA) offered, concentrate supplementation level may be reduced. Grazing pastures in early spring has a large carryover effect on increasing herbage quality and sward utilization (O'Donovan et al., 2004) in the subsequent grazing season; this is an extra incentive for dairy farmers to target grazing in early spring. 
In Ireland, grass growth is seasonal, with little net growth in the November to January period. Therefore, in early spring the grass supply is generally not sufficient to meet the cow's demand. As a result, it is necessary to supplement a grass-based diet with concentrate, first, to ensure the cow is offered adequate feed allowance in early lactation, second, to maximize milk output per cow, and third, to budget the available feed to ensure that the first grazing rotation is not completed before mid-April. Supplementing animals with concentrate has been shown to increase total DMI, and therefore total energy intake (Horan et al., 2006). Concentrate supplementation will allow the animal to express a greater proportion of her milk production potential with minimal BW losses, especially in high-producing dairy cows (Delaby et al., 2001).

Substitution rate $(\mathrm{kg} / \mathrm{kg})$ is the decrease in pasture DMI per kilogram of supplement feed offered. The substitution rate is greater at higher DHA but is affected by other factors such as cow genetic merit (Horan et al., 2006), concentrate allowance (Stockdale, 2000b), pasture quality, parity, and stage of lactation (Bargo et al., 2003). Milk response (MR) to concentrate supplementation, which is the increase in milk yield per kilogram of concentrate offered, is reportedly lower in spring compared with summer (Stockdale, 1999) because of the higher energy content of spring grass. Low substitution rates will result in greater MR to the supplement offered, thus making it more economical to offer the supplement to the animals.

Kennedy et al. (2007c) found no differences in milk yield between cows offered $13 \mathrm{~kg}$ of $\mathrm{DM} / \mathrm{cow}$ per $\mathrm{d}$ or $16 \mathrm{~kg}$ of $\mathrm{DM} /$ cow per $\mathrm{d}$ in early lactation when $4 \mathrm{~kg}$ of DM concentrate was offered. The question remains, however, when pasture constitutes a large proportion of the diet, what is the optimal concentrate level to offer dairy cows in early lactation? The objective of this study was to investigate the effect of concentrate level and DHA on milk production and DMI of spring-calving dairy cows in early lactation.

\section{MATERIALS AND METHODS}

The experiment was conducted at Moorepark Dairy Production Research Center, Fermoy, Co. Cork, Ireland $\left(52^{\circ} 09^{\prime} \mathrm{N} ; 8^{\circ} 16^{\prime} \mathrm{W}\right)$. The soil type is a free-draining acid brown earth of sandy loam to loam texture. The area used is under permanent pasture, with a predominantly perennial ryegrass sward (Lolium perenne L.). The swards were, on average, $4 \mathrm{yr}$ old. Three late-heading diploid cultivars (Twystar, Cornwall, and Gilford) were initially sown.

\section{Animals and Experimental Design}

The experiment investigated the effect of offering 3 levels of concentrate $(0,3$, or $6 \mathrm{~kg}$ of $\mathrm{DM})$ and 2 levels of DHA (13 or $17 \mathrm{~kg}$ of herbage DM/cow per d), which resulted in 6 grazing treatments. Treatments were imposed for an 11-wk period. The experiment was a randomized block design with a $2 \times 3$ factorial arrangement of treatments. Seventy-two Holstein-Friesian dairy cows (24 primiparous and 48 multiparous) were selected from the Moorepark spring-calving dairy herd and balanced on calving date (February 2; SD $9.4 \mathrm{~d}$ ), lactation number (2.5; SD 1.65), first 10-d milk yield of the present lactation (25.7; SD $4.67 \mathrm{~kg}), \mathrm{BW}$ (541; SD $77.5 \mathrm{~kg}$ ), and BCS (2.9; SD 0.49). Animals were then randomly assigned to 1 of the 6 grazing treatments from February 20 to May 7, 2006 (period I). Animals were divided into 2 herds $(n=36)$ and were offered 1 of 2 DHA: $13 \mathrm{~kg}$ of DM/cow per d [low (L)] or $17 \mathrm{~kg}$ of $\mathrm{DM} /$ cow per d [high $(\mathbf{H}) ;>4 \mathrm{~cm}$ ]. These 2 herds were further subdivided into 3 herds $(\mathrm{n}=12)$ and were offered no concentrate (0), $3 \mathrm{~kg}$ of concentrate $(3)$, or $6 \mathrm{~kg}$ of concentrate (6) DM/cow per d. Concentrate was offered in the milking parlor in 2 equal feeds at both the morning and evening milking. The concentrate composition on a fresh weight basis was ground citrus pulp, 0.305; barley, 0.237; maize gluten, 0.249; soybean meal, 0.14; vitamins-minerals, 0.043; and fat, 0.026. The chemical analysis of the concentrate is shown in Table 1.

During the $12 \mathrm{wk}$ (May 8 to August 1) following period I, all animals were reassigned to a 2-treatment grazing study in a randomized block design based on data collected during the final $2 \mathrm{wk}$ of period I. Animals were balanced on milk yield (29.8; SD $5.27 \mathrm{~kg}$ ), fat concentration (34.3; SD $4.65 \mathrm{~g} / \mathrm{kg})$, protein concentration (33.7; SD $2.04 \mathrm{~g} / \mathrm{kg}$ ), lactose concentration (46.2; SD $1.30 \mathrm{~g} /$ $\mathrm{kg}$ ), BW (521; SD $66.6 \mathrm{~kg}$ ), and BCS (2.7; SD 0.31). Period II of the experiment was a crossover design; 6 animals from each treatment were assigned to 1 of 2 herbage allowances $(\mathrm{n}=36)$. During period II, the DHA offered were $17 \mathrm{~kg}$ [medium (MM)] and $21 \mathrm{~kg}$ [high $(\mathbf{M H})]$ of DM/cow per d $(>4 \mathrm{~cm})$. No concentrate was offered during this period. The objective of period II was to investigate the carryover effects of the treatments imposed in period I on milk yield and composition, DMI, BW, and BCS.

\section{Grazing Management}

The experimental grazing area consisted of 25.6 ha, divided into 12 paddocks. The area was closed in rotation the previous autumn. Fresh herbage was allocated to each individual herd on a daily basis after the morning milking. No access to the previous day's grazing area was allowed throughout the experiment. During 
Table 1. Selected herbage and concentrate chemical composition during period I (February 20 to May 7)

\begin{tabular}{|c|c|c|c|c|c|c|}
\hline \multirow[b]{2}{*}{ Item } & \multicolumn{2}{|c|}{$\mathrm{DHA}^{1}$} & \multirow[b]{2}{*}{$\mathrm{SED}^{2}$} & \multirow[b]{2}{*}{ Significance } & \multirow[b]{2}{*}{ Conc. ${ }^{3}$} & \multirow[b]{2}{*}{ SD } \\
\hline & $13 \mathrm{~kg}$ & $17 \mathrm{~kg}$ & & & & \\
\hline $\mathrm{DM}(\%)$ & 19.6 & 19.2 & - & - & 882 & 4.6 \\
\hline \multicolumn{7}{|l|}{ Analysis } \\
\hline OM digestibility ( $\mathrm{g} / \mathrm{kg}$ of $\mathrm{DM})$ & $862^{\mathrm{a}}$ & $869^{\mathrm{b}}$ & 2.3 & $*$ & - & - \\
\hline $\mathrm{CP}(\mathrm{g} / \mathrm{kg}$ of $\mathrm{DM})$ & 256 & 261 & 5.5 & NS & 186 & 16.7 \\
\hline Crude fiber ( $\mathrm{g} / \mathrm{kg}$ of $\mathrm{DM})$ & - & - & - & - & 82 & 17.2 \\
\hline $\mathrm{ADF}(\mathrm{g} / \mathrm{kg}$ of $\mathrm{DM})$ & 206 & 210 & 4.9 & NS & - & - \\
\hline $\mathrm{NDF}(\mathrm{g} / \mathrm{kg}$ of $\mathrm{DM})$ & 370 & 351 & 9.4 & NS & 248 & 40.8 \\
\hline Ash (g/kg of DM) & 74.2 & 71.9 & 2.02 & NS & 100 & 6.6 \\
\hline
\end{tabular}

${ }^{\mathrm{a}, \mathrm{b}}$ Means within a row with different superscripts differ $(P<0.05)$.

${ }^{1} \mathrm{DHA}=$ daily herbage allowance $(\mathrm{kg}$ of $\mathrm{DM} / \mathrm{cow}$ per $\mathrm{d})$.

${ }^{2} \mathrm{SED}=\mathrm{SE}$ of the difference.

${ }^{3}$ Conc. $=$ concentrate offered $(\mathrm{DM} /$ cow per $\mathrm{d})$.

$* P<0.05$.

period I, half of the paddocks were randomly assigned to the low-DHA treatment, with the remaining half assigned to the high-DHA treatment. Cows in the low herbage allowance treatments (L0, L3, and L6) grazed as 3 separate herds adjacent to one another, separated by temporary electric wires, as did the animals offered a high DHA (H0, H3, and H6). Two grazing rotations were completed during period I. Individual herds did not regraze the exact area within a paddock in the second rotation, as was grazed in the first rotation. During period II, the 2 treatments (MM and $\mathrm{MH}$ ) grazed adjacent to one another, separated by a temporary electric wire. Four grazing rotations were completed during period II; mechanical topping to $5.0 \mathrm{~cm}$ of the entire experimental area was completed during the second rotation of period II. Paddocks were dusted with CalMag (Inform Nutrition, Cork, Ireland) on a daily basis to ensure adequate intake of calcium and magnesium in the early-lactation period.

\section{Sward Measurements}

Herbage Mass Determination. Herbage mass ( $>4$ $\mathrm{cm})$ was calculated by cutting 4 strips $(1.2 \times 10 \mathrm{~m})$ for each herbage allowance area twice weekly with an Agria machine (Etesia UK Ltd., Warwick, UK) to determine sward density and herbage mass. Ten grass height measurements were recorded before and after harvesting on each cut strip by using an electronic plate meter (Urban and Caudal, 1990) with a plastic plate $(30 \times 30$ $\mathrm{cm}$ and $4.5 \mathrm{~kg} / \mathrm{m}$, Agrosystèmes, Choiselle, France). All mown herbage from each strip was collected, weighed, and subsampled (approximately $0.5 \mathrm{~kg}$ ). A further subsample of $0.1 \mathrm{~kg}$ of fresh weight of the herbage sample was dried for $16 \mathrm{~h}$ at $90^{\circ} \mathrm{C}$ for $\mathrm{DM}$ determination. On the basis of the above measurements, it was possible to calculate the sward density:

$$
\begin{gathered}
\text { Sward density }=\text { [herbage mass }(\mathrm{kg} \text { of } \mathrm{DM} / \mathrm{ha}) \\
\div(\text { precutting height }- \text { postcutting height }) ; \\
\mathrm{kg} \text { of } \mathrm{DM} / \mathrm{cm} \text { per ha }]
\end{gathered}
$$

Chemical Analysis. Selected herbage samples were collected on a weekly basis during period I and period II for the low- and high-DHA treatments $(\mathrm{n}=2)$ by using a Gardena (Accu 60, Gardena International GmbH, Ulm, Germany) hand shears. Samples were stored at $-20^{\circ} \mathrm{C}$ before being freeze-dried and milled through a $1-\mathrm{mm}$ sieve prior to chemical analysis. The herbage samples were analyzed for $\mathrm{DM}$ content, $\mathrm{ADF}$, NDF (Van Soest, 1963), ash, CP (Leco FP-428, Leco Australia Pty Ltd., Baulkham Hills, New South Wales, Australia), and OM digestibility (Morgan et al., 1989). The chemical analyses of the selected herbage during periods I and II are shown in Tables 1 and 2, respectively. Concentrate samples, collected on a weekly basis during period I, were stored at $-20^{\circ} \mathrm{C}$ and analyzed for DM content, CP, crude fiber, NDF, and ash content. The chemical analysis of the concentrate is shown in Table 1.

Pre- and Postgrazing Sward Heights. Pregrazing sward height was measured daily during period I by recording approximately 30 heights across the 2 diagonals of each grazing area for the low- and high-DHA treatments $(n=2)$ using the electronic plate meter as previously described. The DHA for each herd was calculated by multiplying pregrazing sward height $(>4 \mathrm{~cm})$ by the sward density. After grazing, postgrazing sward heights were also recorded for each of the 6 individual treatments $(n=6)$. During period II, pregrazing sward height was measured daily as described above for the MM and MH treatments $(n=2)$. After grazing, postgrazing sward height was recorded daily for each treatment $(n=2)$. 
Table 2. Selected herbage and chemical composition during period II (May 8 to August 1)

\begin{tabular}{|c|c|c|c|c|}
\hline \multirow[b]{2}{*}{ Item } & \multicolumn{2}{|c|}{$\mathrm{DHA}^{1}$} & \multirow[b]{2}{*}{$\mathrm{SED}^{2}$} & \multirow[b]{2}{*}{ DHA } \\
\hline & $17 \mathrm{~kg}$ & $21 \mathrm{~kg}$ & & \\
\hline $\mathrm{DM}(\%)$ & 18.2 & 17.7 & 0.4 & NS \\
\hline \multicolumn{5}{|l|}{ Analysis $(\mathrm{g} / \mathrm{kg}$ of $\mathrm{DM})$} \\
\hline $\mathrm{OM}$ digestibility $(\mathrm{g} / \mathrm{kg}$ of $\mathrm{DM})$ & 840 & 843 & 2.0 & NS \\
\hline $\mathrm{CP}(\mathrm{g} / \mathrm{kg}$ of $\mathrm{DM})$ & 229 & 220 & 7.1 & NS \\
\hline $\mathrm{ADF}(\mathrm{g} / \mathrm{kg}$ of $\mathrm{DM})$ & 232 & 235 & 4.3 & NS \\
\hline $\mathrm{NDF}(\mathrm{g} / \mathrm{kg}$ of $\mathrm{DM})$ & 403 & 395 & 9.0 & NS \\
\hline Ash $(\mathrm{g} / \mathrm{kg}$ of $\mathrm{DM})$ & $75^{\mathrm{a}}$ & $72^{\mathrm{b}}$ & 1.2 & \\
\hline
\end{tabular}

${ }^{\mathrm{a}, \mathrm{b}}$ Means within a row with different superscripts differ $(P<0.05)$.

${ }^{1} \mathrm{DHA}=$ daily herbage allowance $(\mathrm{kg}$ of $\mathrm{DM} / \mathrm{cow}$ per $\mathrm{d})$.

${ }^{2} \mathrm{SED}=\mathrm{SE}$ of the difference.

$* P<0.05$.

Herbage Utilization. Herbage mass utilization was calculated according to the method described by Delaby and Peyraud (1998). Herbage removed (kg of DM/cow per d) was calculated with the following equation: herbage removed $=($ pregrazing sward height - postgrazing sward height $) \times$ sward density $\times($ area grazed/cow per d). In this experiment, DHA was calculated as $>4 \mathrm{~cm}$. Therefore, if animals grazed below $4 \mathrm{~cm}$, this represented $>100 \%$ utilization.

\section{Animal Measurements}

Milk Production. Milking took place at $0700 \mathrm{~h}$ and $1600 \mathrm{~h}$ daily. Individual milk yields $(\mathrm{kg})$ were recorded at each milking (Dairymaster, Causeway, Co. Kerry, Ireland). Milk fat, protein, and lactose concentrations were calculated weekly from one successive evening (Tuesday) and morning (Wednesday) milking sample for each animal. MilkoScan 203 (DK-3400, Foss Electric, Hillerød, Denmark) was used to determine the concentrations of fat and protein in the milk. Solidscorrected milk yield was calculated by using the equation of Tyrell and Reid (1965). Body weight was recorded weekly by using an electronic portable weighing scale and the Winweigh software package (Tru-test Limited, Auckland, New Zealand). The BCS of the cows was recorded weekly throughout the experimental period. Body condition was scored by one experienced independent observer throughout the experiment on a scale of 1 to 5 (Lowman et al., 1976). Body weight and BCS changes for the 2 experimental periods were calculated by subtracting the mean of the last $2 \mathrm{wk}$ of the period from the mean of the first $2 \mathrm{wk}$ of the period for the relevant measurement.

DMI Measurement and Sample Analysis. Dry matter intake was measured by using the n-alkane technique described by Mayes et al. (1986), as modified by Dillon and Stakelum (1989). All cows were dosed twice daily for $12 \mathrm{~d}$ before both the morning and evening milking with a paper pellet (Carl Roth, GmbH, Karlesruhe, Germany) containing $500 \mathrm{mg}$ of dotriacontane $\left(\mathrm{C}_{32}\right.$-alkane). Fecal grab samples were collected twice daily, from $\mathrm{d} 7$ to 12 , prior to both the morning and evening milking. During the period of fecal sample collection, herbage samples were manually collected with a Gardena hand shears (as described above) at the approximate height to which cows grazed after each morning and evening milking for each treatment to get a representative sample of the herbage grazed. A concentrate sample was collected on a daily basis during each intake run of period I. Both the herbage and concentrate samples were frozen after collection. Fecal grab samples were thawed and bulked (10 $\mathrm{g}$ of each collected sample) by cow. Samples were dried at $40^{\circ} \mathrm{C}$ for $48 \mathrm{~h}$, milled through a 1-mm screen, and chemically analyzed. Herbage samples were bowl chopped, freezedried, and milled in a 1-mm screen prior to chemical analysis. The ratio of herbage $\mathrm{C}_{33}$ to dosed $\mathrm{C}_{32}$ was used to estimate intake. Concentrate samples were subsampled, dried in a $40^{\circ} \mathrm{C}$ oven for $48 \mathrm{~h}$, and milled through a 1-mm screen prior to chemical analysis. The n-alkane concentrations of the dosed pellets, feces, herbage, and concentrate were determined as described by Dillon (1993).

\section{Statistical Analyses}

All statistical analyses were carried out with SAS (SAS Institute, 2002). All sward measurements were analyzed by using ANOVA. The variables included in the model were rotation, week (with week within rotation), DHA, concentrate level, and the interaction between DHA and concentrate. Herbage data from periods I and II were analyzed by using the following model:

$$
\mathrm{Y}_{i j k}=\mu+\mathrm{D}_{i}+\mathrm{C}_{j}+\mathrm{R}_{k}+\mathrm{R}_{k}\left(\mathrm{~W}_{j}\right)+\mathrm{D}_{i} \times \mathrm{C}_{j}+\mathrm{e}_{i j k},
$$

where $\mu$ is the mean; $\mathrm{D}_{i}$ is the DHA ( $i=1$ to 2 ); $\mathrm{C}_{j}$ is the concentrate level ( $j=1$ to 3$) ; R_{k}$ is the rotation ( $k=$ 1 to 2$) ; \mathrm{R}_{k}\left(\mathrm{~W}_{j}\right)$ is the week within rotation ( $k=1$ to 11 ); $\mathrm{D}_{i} \times \mathrm{C}_{j}$ is the interaction between DHA and concentrate level; and $\mathrm{e}_{i j k}$ is the residual error term.

One cow on the L3 treatment and one cow on the L6 treatment were removed from the experiment at the end of period I because of health problems unrelated to the treatment. A third animal was removed from the experiment during period II. These animals were replaced with nonexperimental cows to achieve consistent grazing results. The data collected on these animals was not used for statistical analyses. Animal variables were analyzed as 69 individual variables by using covariate analysis. Daily milk yield, milk composition, 
milk constituent yield, DMI, BW, and BCS were analyzed for each period with the following models:

Period I: $\mathrm{Y}_{i j k}=\mu+\mathrm{D}_{i}+\mathrm{C}_{j}+\mathrm{D}_{i} \times \mathrm{C}_{j}+\mathrm{b}_{1} \mathrm{X}_{i j k}+\mathrm{e}_{i j k}$

Period II: $\mathrm{Y}_{i j k}=\mu+\mathrm{D}_{i}+\mathrm{C}_{j}+\mathrm{D}_{i} \times \mathrm{C}_{j}+\mathrm{S}_{k}+\mathrm{b}_{1} \mathrm{X}_{i j k}+\mathrm{e}_{i j k}$

where $\mathrm{Y}_{i j k}$ represents the response of animal $k$ offered DHA $i$ and concentrate level $j ; \mu$ is the mean; $\mathrm{D}_{i}$ is the DHA ( $i=1$ to 2 ); $\mathrm{C}_{j}$ is the concentrate level ( $j=1$ to 3 ); $\mathrm{D}_{i} \times \mathrm{C}_{j}$ is the interaction of DHA $\times$ concentrate level; $\mathrm{S}_{k}$ is the period II subtreatment; treatment $\mathrm{b}_{1} \mathrm{X}_{i j k}$ is the respective preexperimental variable; and $\mathrm{e}_{i j k}$ is the residual error term.

\section{RESULTS}

\section{Weather}

Climate conditions during the experimental period were atypical. Total monthly rainfall was less than the 10-yr average for the months of February $(26.2 \mathrm{~mm})$, April $(27.8 \mathrm{~mm})$, June $(13.2 \mathrm{~mm})$, and July $(26.1 \mathrm{~mm})$. However, during the months of March $(124.5 \mathrm{~mm})$ and May (127.1 mm), total rainfall was greater than the 10yr average. The total rainfall during the experimental period in $2006(344.9 \mathrm{~mm})$ was $85.3 \mathrm{~mm}$ below the $10-\mathrm{yr}$ average $(430.2 \mathrm{~mm})$. Mean temperatures during April were similar to the 10-yr average. January and February were $0.5^{\circ} \mathrm{C}$ colder than the average. March $\left(6.2^{\circ} \mathrm{C}\right)$ was $1.2^{\circ} \mathrm{C}$ colder than the average. June and July were $1.8^{\circ} \mathrm{C}$ warmer than the 10 -yr average.

\section{Grass and Grazing Management}

In comparison with the 10-yr average (1995 to 2005) for this site, grass growth rates in 2006 were $-2.7,-9.7$,
$-11.4,-22.0$, and $-27.5 \mathrm{~kg}$ of DM/ha per d below normal for the months of February, March, May, June, and July, respectively. During the month of April, grass growth was $+15.8 \mathrm{~kg}$ of $\mathrm{DM} /$ ha per d above the $10-\mathrm{yr}$ mean. The 10-yr mean grass growth yield for this period (February to July, inclusive) was $58.1 \mathrm{~kg}$ of DM/ha per $\mathrm{d}$; however, in 2006 the mean growth rates were $9.6 \mathrm{~kg}$ of DM/ha per d below the 10-yr average. Peak growth occurred in mid-April approximately 1 mo earlier than usual, and this was followed by a rapid decline in normal growth rates, which continued until the end of the experimental period.

The first grazing rotation began on February 20 and was completed on April 4 (44 d); the second grazing rotation finished $26 \mathrm{~d}$ later. The herbage offered to both the low- and high-DHA herds was similar in quality. Table 3 shows the effect of treatment on grazing management during period I. Daily herbage allowance significantly $(P<0.01)$ affected pregrazing herbage mass $(>4 \mathrm{~cm}$ ), which was $1,375 \mathrm{~kg}$ of DM/ha for the low-DHA herds and 1,439 kg of DM/ha for the high-DHA herds during period I. This corresponded to a mean sward density of $230 \mathrm{~kg}$ of DM/ha per $\mathrm{cm}$. Animals offered a high DHA received approximately $20 \%$ more area than those on the low allowance treatment $\left(101 \mathrm{~m}^{2} / \mathrm{cow}\right.$ per d) throughout period I; this equated to a stocking rate of $2.3 \mathrm{cows} / \mathrm{ha}$ for the low-DHA herd and $1.8 \mathrm{cows} / \mathrm{ha}$ for the high-DHA herd. Because the treatments were managed as 6 individual herds, postgrazing sward height ranged from $3.5 \mathrm{~cm}$ (L0) to $5 \mathrm{~cm}(\mathrm{H} 6, P<0.001$; Table 3). Cows grazing the high-DHA treatments had consistently higher postgrazing sward heights than those grazing the low-DHA treatments. At both DHA, for every 1-kg increase in concentrate DM offered, postgrazing sward height increased by $0.1 \mathrm{~cm}$. Herbage utilization $(>4 \mathrm{~cm})$ was highest with the low-DHA treat-

Table 3. Effect of daily herbage allowance and concentrate level $(0,3$, or 6$)$ on pre- and postgrazing sward height, herbage mass, utilization, and area offered during period I (February 20 to May 7)

\begin{tabular}{|c|c|c|c|c|c|c|c|c|c|}
\hline \multirow[b]{2}{*}{ Item } & \multicolumn{6}{|c|}{$\mathrm{DHA}^{1}$} & \multirow[b]{2}{*}{$\mathrm{SED}^{2}$} & \multirow[b]{2}{*}{ DHA } & \multirow[b]{2}{*}{ Conc. ${ }^{3}$} \\
\hline & 0 & 3 & 6 & 0 & 3 & 6 & & & \\
\hline Pregrazing (cm) & 10.0 & 10.0 & 10.0 & 10.2 & 10.2 & 10.2 & 0.31 & * & NS \\
\hline Postgrazing $(\mathrm{cm})$ & $3.5^{\mathrm{a}}$ & $3.8^{\mathrm{b}}$ & $4.1^{\mathrm{c}}$ & $4.4^{\mathrm{d}}$ & $4.6^{\mathrm{e}}$ & $5.0^{\mathrm{f}}$ & 0.19 & $* * *$ & $* * *$ \\
\hline Density (kg of DM/cm per ha) & $228^{\mathrm{a}}$ & $228^{\mathrm{a}}$ & $228^{\mathrm{a}}$ & $232^{\mathrm{b}}$ & $232^{\mathrm{b}}$ & $232^{\mathrm{b}}$ & 1.81 & $* * *$ & NS \\
\hline Herbage mass $>4 \mathrm{~cm}(\mathrm{~kg}$ of DM/ha $)$ & $1,375^{\mathrm{a}}$ & $1,375^{\mathrm{a}}$ & $1,375^{\mathrm{a}}$ & $1,439^{b}$ & $1,439^{b}$ & $1,439^{b}$ & 31.2 & $* *$ & NS \\
\hline Herbage utilization & $1.09^{\mathrm{a}}$ & $1.03^{\mathrm{b}}$ & $0.97^{\mathrm{c}}$ & $0.94^{\mathrm{d}}$ & $0.89^{\mathrm{e}}$ & $0.84^{\mathrm{f}}$ & 0.04 & $* * *$ & $* * *$ \\
\hline
\end{tabular}

${ }^{\mathrm{a}-\mathrm{f}}$ Means within a row with different superscripts differ $(P<0.05)$.

${ }^{1} \mathrm{DHA}=$ daily herbage allowance $(\mathrm{kg}$ of $\mathrm{DM} /$ cow per $\mathrm{d})$.

${ }^{2} \mathrm{SED}=\mathrm{SE}$ of the difference.

${ }^{3}$ Conc. $=$ concentrate level $(\mathrm{kg}$ of DM/cow per $\mathrm{d})$.

$* P<0.05 ; * * P<0.01 ; * * * P<0.001$. 
Table 4. Effect of daily herbage allowance on pre- and postgrazing sward height, herbage mass, utilization, and area offered during period II (May 8 to August 1)

\begin{tabular}{|c|c|c|c|c|}
\hline \multirow[b]{2}{*}{ Item } & \multicolumn{2}{|c|}{$\mathrm{DHA}^{1}$} & \multirow[b]{2}{*}{$\mathrm{SED}^{2}$} & \multirow[b]{2}{*}{ Treatment } \\
\hline & $17 \mathrm{~kg}$ & $21 \mathrm{~kg}$ & & \\
\hline Pregrazing (cm) & 12.7 & 12.5 & 0.22 & NS \\
\hline Postgrazing $(\mathrm{cm})$ & $4.8^{\mathrm{a}}$ & $5.6^{\mathrm{b}}$ & 0.08 & $* * *$ \\
\hline Density (kg of DM/cm per ha) & 212 & 214 & 1.6 & NS \\
\hline Herbage mass $>4 \mathrm{~cm}(\mathrm{~kg}$ of $\mathrm{DM} / \mathrm{ha})$ & 1,813 & 1,785 & 43.2 & NS \\
\hline Area offered $\left(\mathrm{m}^{2} /\right.$ cow per $\left.\mathrm{d}\right)$ & $101^{\mathrm{a}}$ & $130^{\mathrm{b}}$ & 157.1 & $* * *$ \\
\hline Herbage removed (kg/cow) & $15.3^{\mathrm{a}}$ & $16.5^{\mathrm{b}}$ & 0.20 & $* * *$ \\
\hline Herbage utilization & $0.90^{\mathrm{a}}$ & $0.79^{\mathrm{b}}$ & 0.009 & $* * *$ \\
\hline
\end{tabular}

${ }^{\mathrm{a}, \mathrm{b}}$ Means within a row with different superscripts differ $(P<0.05)$.

${ }^{1} \mathrm{DHA}=$ daily herbage allowance $(\mathrm{kg}$ of $\mathrm{DM} /$ cow per $\mathrm{d})$.

${ }^{2} \mathrm{SED}=\mathrm{SE}$ of the difference.

$* P<0.05 ; * * P<0.01 ; * * * P<0.001$.

ment (1.03), whereas cows in the high-DHA treatment utilized 0.89 of the offered herbage.

Total concentrate inclusion in the diet for the $3-\mathrm{kg}$ herds (L3 and H3) from February 20 until May 7 was $231 \mathrm{~kg}$ of DM/cow; animals on the 6 - $\mathrm{kg}$ allowance (L6 and $\mathrm{H} 6$ ) received a total of $462 \mathrm{~kg}$ of $\mathrm{DM} / \mathrm{cow}$ for the duration of the experiment.

During period II, there was no difference in pregrazing sward height (12.7 and $12.5 \mathrm{~cm})$, sward density (212 and $214 \mathrm{~kg}$ of $\mathrm{DM} / \mathrm{ha}$ per $\mathrm{cm})$, or herbage mass $(1,813$ and $1,785 \mathrm{~kg}$ of $\mathrm{DM} / \mathrm{ha}$ ) between the MM and MH treatments, respectively (Table 4). Animals on the MH treatment received approximately $28 \%$ greater area/d $(P<$ $0.001)$ than those on the MM treatment $\left(100 \mathrm{~m}^{2} / \mathrm{cow}\right.$ per d). Offering the higher DHA during period II significantly $(P<0.001)$ increased $(+0.8 \mathrm{~cm})$ postgrazing sward height $(5.6 \mathrm{~cm})$ and herbage removed per cow $/ \mathrm{d}(P$ $<0.001,16.5 \mathrm{~kg}$ of DM) in comparison with the medium DHA (15.3 kg of DM). Sward utilization was significantly increased $(P<0.001)$ when animals were offered the $17-\mathrm{kg}$ DHA (0.90) in comparison with the 21-kg DHA (0.79) during period II.

\section{Animal Performance}

Milk Production. Table 5 presents the production performance of the 6 treatments during period I. There was no interaction between DHA and concentrate allowance throughout the 2 experimental periods (periods I and II). No quadratic effect of concentrate was detected. Results from period I indicate that increasing DHA significantly $(P<0.05)$ increased milk yield $(+1.85$ $\mathrm{kg} / \mathrm{cow}$ per d); $\mathrm{SCM}(+1.8 \mathrm{~kg} / \mathrm{cow}$ per d), protein $(+79.5$ $\mathrm{g} /$ cow per d), and lactose $(+86.8 \mathrm{~g} /$ cow per d) yields; protein concentration $(+0.8 \mathrm{~g} / \mathrm{kg})$; and mean BW $(+12.3$ $\mathrm{kg}$ ). Mean BCS and end-point BCS were also significantly higher $(P<0.05)$ for herds offered the high DHA $(+0.13$ and +0.15$)$, respectively. There was a positive linear response $(P<0.001)$ in milk yield to concentrate supplementation throughout period I. Mean milk yield of unsupplemented animals was $26.8 \mathrm{~kg} / \mathrm{cow}$ per d; offering concentrate increased mean milk yield by $1.8 \mathrm{~kg} /$ cow per d $(3 \mathrm{~kg})$ and $4.3 \mathrm{~kg} / \mathrm{cow}$ per d $(6 \mathrm{~kg})$. Milk lactose concentration increased linearly $(P<0.05)$ with concentrate level, as did SCM, milk fat, milk protein, and milk lactose yields. Concentrate had a positive effect $(P<0.05)$ on milk fat yield, the unsupplemented herds recorded a milk fat yield of $1,004 \mathrm{~g} / \mathrm{cow}$ per d; this increased when concentrate was offered by $67 \mathrm{~g} /$ cow per $\mathrm{d}(3 \mathrm{~kg})$ and $129 \mathrm{~g} /$ cow per $\mathrm{d}(6 \mathrm{~kg})$. The unsupplemented herds yielded $878 \mathrm{~g} / \mathrm{cow}$ per d of milk protein, which increased by 67 and $161 \mathrm{~g} / \mathrm{cow}$ per $\mathrm{d}$ when animals were supplemented with 3 and $6 \mathrm{~kg}$ of concentrate, respectively. Milk lactose yield increased linearly $(P$ $<0.001$ ) with concentrate level; the yields were 1,228 (unsupplemented), 1,332 (3 kg), and 1,452 g/cow per d $(6 \mathrm{~kg})$. Solids-corrected milk increased $(P<0.001)$ by $1.8 \mathrm{~kg} / \mathrm{cow}$ per $\mathrm{d}(3 \mathrm{~kg})$ and $3.7 \mathrm{~kg} / \mathrm{cow}$ per d $(6 \mathrm{~kg})$, compared with the unsupplemented herds $(24.2 \mathrm{~kg} / \mathrm{cow}$ per d). There was a significant increase $(P<0.01)$ in mean BW as concentrate increased from 0 to $3 \mathrm{~kg}$ (506 and $524 \mathrm{~kg}$, respectively); there was no further increase in BW when $6 \mathrm{~kg}$ of concentrate $(519 \mathrm{~kg})$ was offered. Concentrate supplementation level had no effect on mean BCS or end-point BCS during period I. Although not significant, fat concentration decreased as supplementation increased for the high DHA, whereas at the low DHA, fat concentration increased $(+1.4 \mathrm{~g} / \mathrm{kg})$ for the $3 \mathrm{~kg}$ of concentrate allowance (L3) and then decreased for the L6 treatments to a value similar to that achieved by the L0 herd $(3.66 \mathrm{~g} / \mathrm{kg})$.

Table 6 presents the carryover effect of early-lactation feeding management on midlactation milk performance. During period II, the high-DHA treatment $(\mathrm{MH})$ had a greater milk yield $(+0.82 \mathrm{~kg} / \mathrm{d}, P<0.01)$, but 
Table 5. Effect of daily herbage allowance and concentrate level $(0,3$, or 6$)$ on milk production performance of spring-calving cows in early lactation (period I: February 20 to May 7)

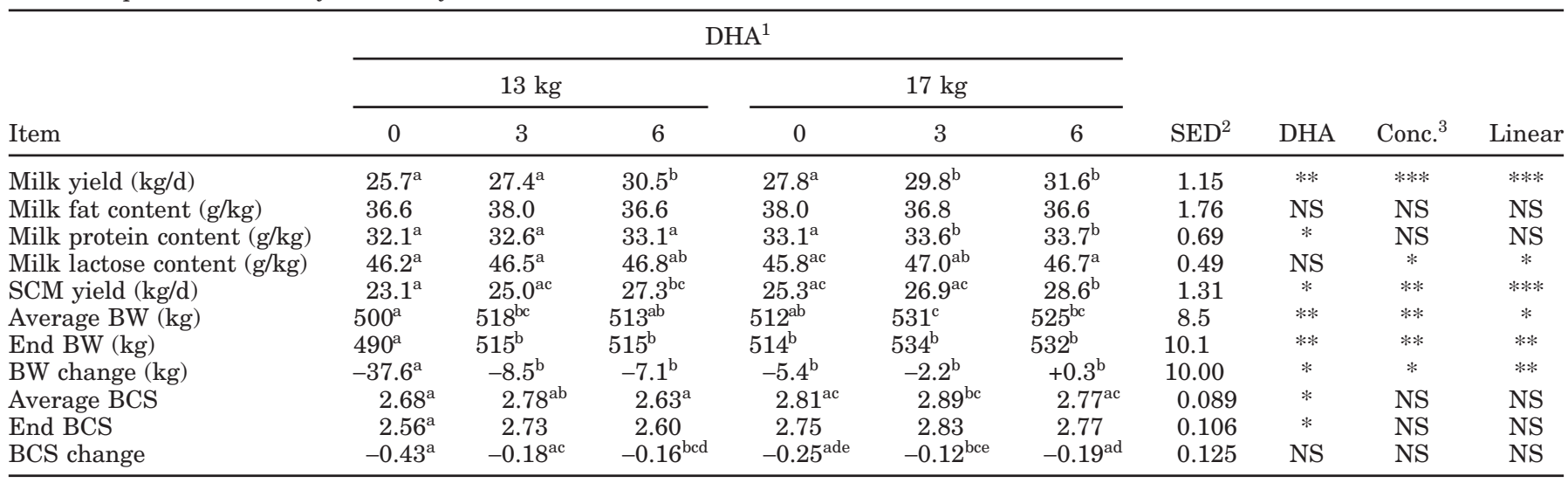

${ }^{\mathrm{a}-\mathrm{e}}$ Means within a row with different superscripts differ $(P<0.05)$.

${ }^{1} \mathrm{DHA}=$ daily herbage allowance $(\mathrm{kg}$ of $\mathrm{DM} /$ cow per $\mathrm{d})$.

${ }^{2} \mathrm{SED}=\mathrm{SE}$ of the difference

${ }^{3}$ Conc. $=$ concentrate level $(\mathrm{kg}$ of $\mathrm{DM} /$ cow per $\mathrm{d})$.

$* P<0.05 ; * * P<0.01 ; * * * P<0.001$

tended to have a reduced milk fat yield $(-5.9 \mathrm{~g} / \mathrm{cow}$ per $\mathrm{d}, P<0.08)$ and increased milk lactose concentration $(+0.39 \mathrm{~g} / \mathrm{kg}, P<0.05)$ in comparison with the MM treatment $[21.1 \mathrm{~kg} / \mathrm{d}$ (milk yield), $786.8 \mathrm{~g} / \mathrm{cow}$ per d (milk fat yield), and $45.3 \mathrm{~g} / \mathrm{kg}$ (milk lactose concentration)]. The MH herd had significantly $(P<0.01)$ greater milk protein yield $(+30.6 \mathrm{~g} / \mathrm{cow}$ per $\mathrm{d})$, milk lactose yield $(+45.2 \mathrm{~g} / \mathrm{cow}$ per d), mean BW (+6.3 kg), and end-point $\mathrm{BW}(+12.1 \mathrm{~kg})$ and had higher BW gain $(+12.1 \mathrm{~kg})$ than the MM herd, which had corresponding values of 681.7 g/cow per d (milk protein yield), $954.0 \mathrm{~g} / \mathrm{cow}$ per d (milk lactose yield), $533.7 \mathrm{~kg}$ (mean BW), $540.7 \mathrm{~kg}$ (end-point $\mathrm{BW}$ ), and $24.2 \mathrm{~kg}$ (BW gain). Mean and end-point BCS were unaffected by DHA during period II.

Previous DHA continued to have a significant carryover effect on milk protein concentration $(P<0.05)$, BW change, mean BCS, and end-point BCS $(P<0.001)$ during period II. Concentrate supplementation during period I continued to have a significant $(P<0.01)$ carryover effect on milk yield, milk fat, milk protein, milk lactose, and SCM yields; mean BW; end-point BW; BW change; and mean BCS during period II.

Table 6. Carryover effect of daily herbage allowance and concentrate level $(0,3$, or 6$)$ offered in early lactation on milk production performance of spring-calving cows in midlactation (period II: May 8 to August 1)

\begin{tabular}{|c|c|c|c|c|c|c|c|c|c|}
\hline \multirow[b]{2}{*}{ Item } & \multicolumn{6}{|c|}{$\mathrm{DHA}^{1}$} & \multirow[b]{2}{*}{$\mathrm{SED}^{2}$} & \multirow[b]{2}{*}{ DHA } & \multirow[b]{2}{*}{ Conc. } \\
\hline & 0 & 3 & 6 & 0 & 3 & 6 & & & \\
\hline Milk fat content $(\mathrm{g} / \mathrm{kg})$ & $34.4^{\mathrm{a}}$ & $36.1^{\mathrm{ab}}$ & $37.4^{\mathrm{b}}$ & $37.2^{\mathrm{b}}$ & $36.8^{\mathrm{b}}$ & $37.2^{\mathrm{b}}$ & 1.19 & NS & NS \\
\hline Milk protein content $(\mathrm{g} / \mathrm{kg})$ & $31.6^{\mathrm{a}}$ & $32.3^{\mathrm{ab}}$ & $32.7^{\mathrm{b}}$ & $32.9^{\mathrm{b}}$ & $32.7^{\mathrm{b}}$ & $32.4^{\mathrm{b}}$ & 0.34 & $*$ & NS \\
\hline Milk lactose content ( $\mathrm{g} / \mathrm{kg})$ & 45.8 & 45.5 & 45.3 & 44.9 & 46.0 & 45.5 & 0.27 & NS & $*$ \\
\hline End BW $(\mathrm{kg})$ & $537^{\mathrm{a}}$ & $558^{\mathrm{b}}$ & $544^{\mathrm{ac}}$ & $537^{\mathrm{a}}$ & $554^{\mathrm{b}}$ & $551^{\mathrm{bc}}$ & 4.8 & NS & $* * *$ \\
\hline BW change (kg) & $48.8^{\mathrm{a}}$ & $43.2^{\mathrm{a}}$ & $31.8^{\mathrm{b}}$ & $22.0^{\mathrm{bc}}$ & $22.8^{\mathrm{b}}$ & $12.8^{\mathrm{c}}$ & 4.79 & $* * *$ & $* * *$ \\
\hline Average BCS & $2.65^{\mathrm{a}}$ & $2.55^{\mathrm{a}}$ & $2.53^{\mathrm{a}}$ & $2.73^{\mathrm{b}}$ & $2.86^{\mathrm{b}}$ & $2.71^{\mathrm{c}}$ & 0.040 & $* * *$ & $* *$ \\
\hline End BCS & $2.50^{\mathrm{a}}$ & $2.57^{\mathrm{ac}}$ & $2.48^{\mathrm{a}}$ & $2.73^{\mathrm{b}}$ & $2.77^{\mathrm{b}}$ & $2.65^{\mathrm{bc}}$ & 0.074 & $* * *$ & NS \\
\hline BCS change & -0.07 & -0.08 & -0.13 & -0.03 & -0.06 & -0.17 & 0.090 & NS & NS \\
\hline
\end{tabular}

${ }^{\mathrm{a}-\mathrm{e}}$ Means within a row with different superscripts differ $(P<0.05)$.

${ }^{1} \mathrm{DHA}=$ daily herbage allowance $(\mathrm{kg}$ of $\mathrm{DM} /$ cow per $\mathrm{d})$.

${ }^{2} \mathrm{SED}=\mathrm{SE}$ of the difference.

${ }^{3}$ Conc. $=$ concentrate level $(\mathrm{kg}$ of $\mathrm{DM} /$ cow per $\mathrm{d})$.

$* P<0.05 ; * * P<0.01 ; * * * P<0.001$. 
Table 7. Mean herbage and total DMI values measured during period I (February 20 to May 7) and period II (May 8 to August 1)

\begin{tabular}{|c|c|c|c|c|c|c|c|c|c|}
\hline \multirow[b]{3}{*}{ Item } & \multicolumn{6}{|c|}{ DHA $^{1}$} & \multirow[b]{3}{*}{$\mathrm{SED}^{2}$} & \multirow[b]{3}{*}{ DHA } & \multirow[b]{3}{*}{ Conc. $^{3}$} \\
\hline & \multicolumn{3}{|c|}{$13 \mathrm{~kg}$} & \multicolumn{3}{|c|}{$17 \mathrm{~kg}$} & & & \\
\hline & 0 & 3 & 6 & 0 & 3 & 6 & & & \\
\hline \multicolumn{10}{|l|}{ DMI (period I) } \\
\hline Herbage intake (kg of DM/d) & $13.6^{\mathrm{a}}$ & $13.9^{\mathrm{a}}$ & $12.5^{\mathrm{a}}$ & $15.8^{\mathrm{b}}$ & $15.5^{\mathrm{b}}$ & $13.4^{\mathrm{a}}$ & 0.76 & $* * *$ & ** \\
\hline Concentrate intake ( $\mathrm{kg}$ of $\mathrm{DM} / \mathrm{d})$ & - & 3 & & - & 3 & 6 & & & \\
\hline $\mathrm{TDMI}^{4}(\mathrm{~kg}$ of $\mathrm{DM} / \mathrm{d})$ & $13.6^{\mathrm{a}}$ & $16.9^{\mathrm{b}}$ & $18.5^{\mathrm{bd}}$ & $15.8^{\mathrm{b}}$ & $18.5^{\mathrm{bd}}$ & $19.4^{\mathrm{cd}}$ & 0.76 & $* * *$ & **** \\
\hline \multicolumn{10}{|l|}{ DMI (period II) } \\
\hline Herbage intake $^{5}(\mathrm{~kg}$ of $\mathrm{DM} / \mathrm{d})$ & 17.8 & 18.2 & 18.3 & 17.5 & 18.9 & 17.2 & 0.86 & NS & NS \\
\hline \multicolumn{10}{|c|}{ a-d Means within a row with different superscripts differ $(P<0.05)$. } \\
\hline \multicolumn{10}{|c|}{${ }^{1} \mathrm{DHA}=$ daily herbage allowance $(\mathrm{kg}$ of $\mathrm{DM} /$ cow per $\mathrm{d})}$. \\
\hline \multicolumn{10}{|c|}{${ }^{2} \mathrm{SED}=\mathrm{SE}$ of the difference. } \\
\hline \multicolumn{10}{|c|}{${ }^{3}$ Conc. $=$ concentrate level $(\mathrm{kg}$ of DM/cow per d). } \\
\hline \multirow{2}{*}{\multicolumn{10}{|c|}{$\begin{array}{l}{ }^{4} \mathrm{TDMI}=\text { total DMI; TDMI was calculated by assuming animals consumed all concentrate offered and by } \\
\text { adding the offered concentrate allowance to actual herbage intake, which was calculated by using the n- } \\
\text { alkane technique. }\end{array}$}} \\
\hline & & & & & & & & & \\
\hline \multicolumn{10}{|c|}{${ }^{5}$ No concentrate was offered during period II. } \\
\hline
\end{tabular}

DMI and Herbage Substitution. There was no interaction between DHA and concentrate allowance for grass DMI (GDMI) or total DMI (TDMI). Table 7 shows the mean GDMI and TDMI for the 2 experimental periods. During period I, cows grazing the low DHA had significantly lower $(P<0.001,-1.6 \mathrm{~kg})$ GDMI $(13.3 \mathrm{~kg} /$ cow per d) and TDMI ( $16.3 \mathrm{~kg} / \mathrm{cow}$ per $\mathrm{d}$ ) than the highDHA herds. The response in GDMI to extra herbage offered was $0.4 \mathrm{~kg}$ of GDMI/kg of DM offered. Concentrate supplementation significantly $(P<0.001)$ increased TDMI. The unsupplemented herd had a TDMI of $14.7 \mathrm{~kg} / \mathrm{cow}$ per $\mathrm{d}$, whereas the herds offered 3 and $6 \mathrm{~kg}$ had a TDMI of 17.7 and $18.9 \mathrm{~kg} / \mathrm{cow}$ per d, respectively. There was no significant difference in GDMI between the unsupplemented herds and those receiving $3 \mathrm{~kg}$ of concentrate (14.7 kg of DM/cow per d). Grass DMI of herds offered $6 \mathrm{~kg}$ of concentrate was $1.8 \mathrm{~kg} / \mathrm{cow}$ per d lower $(P<0.01)$ than that of the unsupplemented herds and those receiving $3 \mathrm{~kg}$ of concentrate.

During period II, treatment ( $\mathrm{MM}$ and $\mathrm{MH}$ ) had no effect on GDMI. Grass DMI was $0.9 \mathrm{~kg} /$ cow per d less on the MM treatment $(17.5 \mathrm{~kg})$ than on the $\mathrm{MH}$ treatment $(18.4 \mathrm{~kg})$. Daily herbage allowance and concentrate had no carryover effect on GDMI. Animals previously allocated to the H6 treatment had the lowest GDMI (17.2 $\mathrm{kg} / \mathrm{cow}$ per d), which was $1.7 \mathrm{~kg} / \mathrm{cow}$ per d lower than that of the $\mathrm{H} 3$ treatment $(P<0.05)$. On average, during period II the animals offered a low DHA during period I tended to have intakes of $0.21 \mathrm{~kg} / \mathrm{cow}$ per $\mathrm{d}$ greater than those offered a high DHA; however, this difference was not significant.

\section{DISCUSSION}

In recent years, provision of spring grass has increased because of refinements in autumn closing management (Roche et al., 1996), use of new grass varieties (Gilliland, 1995), and applying the principles of feed budgeting (O'Donovan, 2000). Despite these advances, even in the optimal scenario, grass supply is still limited in spring, which leaves a requirement to further increase the energy level in the diet of the lactating cow during this period. This retains the necessity to supplement with concentrate or other available supplements (grass silage, maize silage, etc.) to achieve a high level of milk production while maintaining a long first-grazing rotation. Long first rotations ensure that sufficient grass is available to the animal until grass growth exceeds demand. The question remains: can offering higher concentrate levels increase milk production performance with higher herbage allowances in early spring without compromising grass utilization?

\section{Spring Feed Allowance and Herbage Utilization}

Approximately 0.8 to $1.0 \mathrm{t}$ of herbage/cow is required to offer the herd a diet of $80 \%$ grazed grass from February to mid-April with the remainder as concentrate. This represents an optimistic but achievable target for grassland dairy farmers. In spring, it is possible to achieve high grass utilization in line with the level of herbage offered. Kennedy et al. (2007c) found lower postgrazing sward heights with decreasing DHA, whereas offering concentrate supplementation resulted 
in higher postgrazing sward heights. The grazing residual results of the current study represent high grass utilization, in agreement with the findings of the above author. Bargo et al. (2003) stated that if the aim is to maximize pasture DMI of high-producing dairy cows, management must ensure unrestricted pasture quality and quantity, which is found only in short periods during the spring. Unrestricted pasture conditions (i.e., high DHA) implies low grass utilization [kg of pasture $\mathrm{DMI} / \mathrm{kg}$ of DHA $(>4 \mathrm{~cm})<62 \%$; Christie et al., 2000]. The current study shows that it is possible to achieve high utilization levels without compromising dairy cow performance. During period I, animals on the low DHA continually achieved higher sward utilization rates than those offered a high DHA. Supplementing animals reduced grass utilization, but to lower levels than that suggested by Stakelum (1986), when herbage allowance was measured from ground level. The extent of the reduction in pasture utilization will depend on both DHA and supplementation level. For each 1-kg increase in concentrate offered, postgrazing sward height increased by $0.1 \mathrm{~cm}$ (range 0.08 to $0.12 \mathrm{~cm}$ ). Kennedy et al. (2007c) found similar increases (mean $0.12 \mathrm{~cm} / \mathrm{kg}$ of concentrate) in postgrazing sward height. The postgrazing sward heights achieved in the current study are well within the practical guidelines set out by Kennedy et al. (2007a). However, grazing leniently in spring because of the allocation of high DHA to increase cow performance will result in mid- and late-season sward quality deterioration and a sharp reduction in animal performance (Mayne et al., 1987; Hoogendoorn et al., 1992; Kennedy et al., 2007b). The possibilities of increasing DMI by increasing DHA are limited; Kennedy et al. (2007c) found very small increases in grass DMI when increasing DHA from 13 to $19 \mathrm{~kg}$ of DM/cow per d. Finding the correct balance between DHA and concentrate level is likely to be beneficial in terms of both an animal production response and grass utilization perspective.

\section{Substitution Rate and MR}

Substitution rate and MR to supplementation are affected by several pasture, animal, and supplement factors (Stockdale, 2000a,b). The most important pasture-related factors are DHA, pasture height, pasture species, pasture mass, and pasture quality. In the current study, given that the animal genetic merit and concentrate type were similar and the stated sward parameters were managed to be equal for all treatments, the main differentiating factor was herbage allowance. Substitution rate is one of the main factors explaining the variation in observed MR to concentrate supplementation (Kellaway and Porta, 1993).
No substitution was observed in the current experiment when $3 \mathrm{~kg}$ of concentrate was offered at either DHA. Grass substitution did occur at the high concentrate levels. At low DHA, the substitution rate was 0.19 $\mathrm{kg} / \mathrm{kg}$ of concentrate. This increased to $0.39 \mathrm{~kg} / \mathrm{kg}$ of concentrate at the high DHA when $6 \mathrm{~kg}$ of DM concentrate was offered. The main reason for the low herbage substitution levels was the level of DHA offered. Stockdale (1999) reported average substitution levels of a $0.43-\mathrm{kg}$ reduction in pasture intake $/ \mathrm{kg}$ of DM concentrates consumed (range: 0,3 , or $5 \mathrm{~kg}$ of DM concentrates offered) for cows at a similar stage of lactation, with DMI of unsupplemented animals in the range of 14.1 to $16.4 \mathrm{~kg}$ of DM herbage/cow per d. Kennedy et al. (2007c) recorded substitution rates ranging from 0.25 to $0.45 \mathrm{~kg}$ of DM herbage/ $\mathrm{kg}$ of DM concentrate. Faverdin et al. (1991) showed that the observed substitution rate of dairy cows was related to the energy status of the cow without concentrate supplementation. When the animal was underfed, the concentrate input only slightly penalized grass DMI and appreciably improved the energy balance of the animals, which resulted in a simultaneous increase in milk yield, protein concentration, and BW gain (Coulon and Rémond, 1991). It is clear from the intake results that the L0 herds were restricted to 0.70 of the intake capacity of the high feed allowance herd (H6). Total DMI increased from $13.6 \mathrm{~kg}$ of $\mathrm{DM} / \mathrm{d}(2.72 \%$ of BW) to $19.4 \mathrm{~kg}$ of $\mathrm{DM} / \mathrm{d}(3.78 \%$ of BW). Such an increase is incrementally better than that reported by Bargo et al. (2002), given the increases in DHA reported in that study. An interesting finding from the current study was the similar total DMI performance achieved by the L6 and H3 herds. This shows that the pasture substitution rate can be reduced, ensuring both high milk performance and grass utilization without offering excessive levels of concentrate. McEvoy et al. (2007) recommended the n-alkane technique as the most accurate method to estimate individual animal intakes. The experimental area used in the current study was dominated by perennial ryegrass swards. The n-alkane technique has been shown to have less variable results with these swards than other methods of herbage intake estimation. However, overestimation of herbage intake, compared with the animals' energy requirements, may occur (Smit et al., 2005).

Marginal MR was large at the low-DHA level but reduced at the high-DHA level. Many previous studies have reported milk production increases in response to concentrate feeding (Delaby et al., 2001; Bargo et al., 2002; Horan et al., 2005); however, the early-lactation period was not investigated. Kennedy et al. (2007c) found that the mean response to concentrate was 1.1 $\mathrm{kg}$ of milk/kg of DM concentrate in early lactation, but 
with a herd containing $45 \%$ primiparous animals. These response levels were higher than those previously reported by Kennedy et al. (2002; $0.66 \mathrm{~kg}$ of milk/ $\mathrm{kg}$ of concentrate DM) and Horan et al. (2005; $1.00 \mathrm{~kg}$ of milk/kg of concentrate DM), both experiments had a similar concentrate input and animals of similar genetic merit, with MR to concentrate measured across the entire lactation of the animals. Milk response to concentrate is reportedly lower in spring compared with summer (Stockdale, 1999). What is clear from the current study is the declining MR when a greater grass allowance is offered. In a number of experiments with cows in early to midlactation (40 to 182 DIM), an average overall response of $1 \mathrm{~kg}$ of milk/ $/ \mathrm{kg}$ of concentrate offered was found; the range in MR was 0.60 (Sayers, 1999) to $1.45 \mathrm{~kg}$ of milk/kg of concentrate (Gibb et al., 2002). Peyraud et al. (2001), reviewing 7 concentrate studies at pasture, reported a similar milk production response to concentrate offered. Bargo et al. (2003) concluded that milk production of high-producing cows ( $>28 \mathrm{~kg}$ of milk/cow per d) in early lactation increases linearly as the amount of concentrate increases from 1.8 to $10 \mathrm{~kg}$ of $\mathrm{DM} / \mathrm{d}$, with an overall $\mathrm{MR}$ of $1 \mathrm{~kg}$ of milk/ $\mathrm{kg}$ of concentrate. The findings of the current study suggest that the MR to concentrate in early lactation (60 DIM) depends on the level of herbage offered. At $13 \mathrm{~kg}$ of DM DHA, the mean MR was 0.56 and 0.80 $\mathrm{kg}$ of milk/ $\mathrm{kg}$ of concentrate offered for 3 and $6 \mathrm{~kg}$ of concentrate, respectively. Offering $17 \mathrm{~kg}$ of DM DHA in early lactation resulted in a MR of between $0.67 \mathrm{~kg}$ $(3 \mathrm{~kg})$ and $0.63 \mathrm{~kg}(6 \mathrm{~kg})$ of milk/kg of concentrate, respectively.

Herbage DMI increased by $2.2 \mathrm{~kg} / \mathrm{cow}$ with an increase of $0.9 \mathrm{~cm}$ in postgrazing sward height as DHA increased from 13 to $17 \mathrm{~kg}$ of $\mathrm{DM} /$ cow per $\mathrm{d}$ for the unsupplemented herds. This response level $(0.55 \mathrm{~kg}$ of $\mathrm{DMI} / \mathrm{kg}$ of DHA) is large, as is the milk production response $(0.5 \mathrm{~kg}$ of milk $/ \mathrm{kg}$ of extra grass DM offered or $0.95 \mathrm{~kg}$ of milk/kg of increase in GDMI above $13 \mathrm{~kg}$ of grass allowance). Delagarde et al. (2004) found an increase in daily herbage intake of 0.2 to $0.25 \mathrm{~kg}$ of $\mathrm{DMI} / \mathrm{kg}$ of DHA when DHA was calculated as $>5.0 \mathrm{~cm}$. Stakelum and Dillon (1990) found a lower response with animals in midlactation, showing an $0.80-\mathrm{kg}$ increase in milk yield for each extra 1-kg increase in GDMI $\left(r^{2}=0.99\right)$.

\section{Milk Composition, BW, and BCS}

Milk fat concentration was not influenced by concentrate level, which agrees with the early-lactation studies of Dillon et al. (2002) and Kennedy et al. (2007c), but is in conflict with the midlactation studies (Delaby et al., 2001; Bargo et al., 2002) in which animals were supplemented with greater than $5 \mathrm{~kg} / \mathrm{cow}$ per d, possibly because of a dilution effect of milk yield increasing more rapidly than milk fat when concentrate is introduced into the diet in midlactation. Contrary to the observations of Le Du et al. (1979) and Greenhalgh et al. (1967), there was no effect of DHA on milk fat concentration. Results of the current study also agree with the findings of Maher et al. (2003). Milk protein concentration was affected by DHA; this effect was probably inflated by the low milk protein concentration achieved by the L0 herd. Maher et al. (2003) found milk protein concentration to increase linearly with increasing DHA. Kennedy et al. (2007c) found no effect of DHA on milk protein concentration.

Supplementing cows with concentrate increased BW $(+16 \mathrm{~kg})$ and reduced BW loss, a finding similar to those of previous authors (Dillon et al., 2002; Delaby et al., 2003; Horan et al., 2005). Offering a higher DHA increased mean $\mathrm{BW}(+12.3 \mathrm{~kg})$ and end $\mathrm{BW}(+20.5 \mathrm{~kg})$ and reduced BW change. Kennedy et al. (2007c) found a linear increase in BW as DHA increased during early lactation. The effects of DHA on BW are very much dependent on the level of grass offered. It is apparent that some of the animals had to mobilize a greater proportion of body reserves during the study because of high restriction levels. Mean BCS $(+0.13)$ and endpoint BCS $(+0.15)$ were positively influenced by DHA. Kennedy et al. (2007c) reported no effect of DHA on BCS.

\section{Carryover Period}

Generally when reporting the results of component studies, the direct effects are the main interest; however, in the current study and in that of Kennedy et al. (2007c), large treatment carryover effects were found in the period subsequent to the main study. Offering an inadequate level of feed in early lactation has been shown to reduce subsequent milk yield (Roche, 2007). The milk solids concentration established in early lactation also appears to extend into later lactation (Broster et al., 1969). The large carryover effects of the current study are a consequence of the extended study period (11 wk), with some restrictive treatments such a time period resulting in a larger response level in the carryover period. The significant carryover effects in the weeks after the experimental period may be explained by the large treatment effects on milk production (Gordon et al., 2000). Concentrate supplementation had significant carryover effects on milk yield, lactose content, and SCM, whereas DHA significantly affected milk protein concentration. Both concentrate supplementation and DHA had carryover effects on BW and BCS. Kennedy et al. (2007c) found no carryover effect of DHA on 
any milk production parameter; however, there was an effect of DHA on BW and BCS change. Concentrate supplementation affected milk yield, milk lactose, SCM, and $\mathrm{BW}$ (change and end point), which are similar to the findings of the current study.

\section{CONCLUSIONS}

In grazing, a balance must be found between grass utilization and achieving high milk production performance. The current study supports the concept that spring-calving dairy cows should have access to grass as early as possible in spring and that available grass should be budgeted until grass growth is sufficient to meet requirements for milk production (O'Donovan, 2000). Milk production performance was increased when a high level of DHA (17 kg of grass DM) was offered. Supplementing with up to $6 \mathrm{~kg}$ of concentrate resulted in a linear increase in milk production. From an early spring feed-budgeting scenario, when grass supply is in deficit, offering concentrate with an adequate level of DHA has the additive effects of maintaining the grazing rotation at the target length as well as ensuring that the herd is adequately fed. The current study shows that in spring, both these objectives can be attained by offering $17 \mathrm{~kg}$ of DM DHA with $3 \mathrm{~kg}$ of $\mathrm{DM} /$ cow of concentrate in the early-lactation period. However, in scenarios in which grass supply is limited, we conclude that offering a low DHA (13 kg of DM/ cow per d) and $6 \mathrm{~kg}$ of DM/cow of concentrate will also support a high level of milk production.

\section{ACKNOWLEDGMENTS}

The authors wish to thank M. Feeney, F. Flynn, J. Nash, C. Fleming and N. Galvin for their technical assistance. Gratitude is also expressed to all the Moorepark farm staff for their care of the experimental animals and assistance with measurements throughout the study.

\section{REFERENCES}

Bargo, F., L. D. Muller, J. E. Delahoy, and T. W. Cassidy. 2002. Milk response to concentrate supplementation of high producing dairy cows grazing at two pasture allowances. J. Dairy Sci. 85:17771792 .

Bargo, F., L. D. Muller, E. S. Kolver, and J. E. Delahoy. 2003. Invited review: Production and digestion of supplemented dairy cows on pasture. J. Dairy Sci. 86:1-42.

Broster, W. H., V. J. Broster, and T. Smith. 1969. Experiments on the nutrition of the dairy heifer. VIII. Effect on milk production of level of feeding at two stages of the lactation. J. Agric. Sci. $72: 229-245$.

Christie, H., C. S. Mayne, A. S. Laidlaw, D. M. Patterson, and D. A. McGilloway. 2000. Effect of sward manipulation and milk yield potential on herbage intake of grazing dairy cows. Page 79 in Grazing Management. Br. Grassl. Soc. Occas. Symp. No. 34. A. J. Rook and P. D. Penning, ed. Br. Grassl. Soc., Reading, UK.
Coulon, J. B., and B. Rémond. 1991. Variations in milk output and milk protein content in response to the level of energy supply to the dairy cow: A review. Livest. Prod. Sci. 29:31-47.

Delaby, L., and J. L. Peyraud. 1998. Effect d'une reduction simultanée de la fertilisation azotée et du chargement sur les performances des vaches laitières et la valorisation du pâturage. Ann Zootech. 47:17-39.

Delaby, L., J. L. Peyraud, and R. Delagarde. 2001. Effect of the level of concentrate supplementation, herbage allowance and milk yield at turn-out on the performance of dairy cows in mid lactation at grazing. Anim. Sci. 53:171-181.

Delaby, L., J. L. Peyraud, J. R. Peccatte, N. Foucher, and G. Michel. 2003. The effect of two contrasting grazing managements and level of concentrate supplementation on the performance of grazing dairy cows. Anim. Res. 52:437-460.

Delagarde, R., P. Faverdin, C. Baratte, and J. L. Peyraud. 2004. Právoir l'ingestion et la production des vache laitiàres: GrazeIn, un modàle pour raisonner l'alimentation au pâturage. Ren. Rech. Rumin. 11:295-298.

Dillon, P. 1993. The use of n-alkanes as markers to determine intake, botanical composition of available or consumed herbage in studies of digesta kinetics with dairy cows. PhD Thesis. Natl. Univ. of Ireland, Dublin, Ireland.

Dillon, P., S. Crosse, B. O'Brien, and R. W. Mayes. 2002. The effect of forage type and level of concentrate supplementation on the performance of spring-calving dairy cows in early lactation. Grass Forage Sci. 57:212-223.

Dillon, P., J. R. Roche, L. Shalloo, and B. Horan. 2005. Optimising financial return from grazing in temperate pastures. Pages 131147 in XXth Int. Grassl. Congr., Cork, Ireland. Wageningen Academic Publishers, Wageningen, the Netherlands.

Dillon, P., and G. Stakelum. 1989. Herbage and dosed alkanes as a grass management technique for dairy cows. Ir. J. Agric. Res. 8:104. (Abstr.)

Faverdin, P., J. P. Dulphy, J. B. Coulon, R. Vérité, J. P. Garel, J. Rouel, and B. Marquis. 1991. Substitution of roughage by concentrates by dairy cows. Livest. Prod. Sci. 27:137-156.

Gibb, M. J., C. A. Huckle, and R. Nuthall. 2002. Effects of level of concentrate supplementation on grazing behaviour and performance by lactating dairy cows grazing continuously stocked grass swards. Anim. Sci. 74:319-335.

Gilliland, T. J. 1995. Effect of harvest date and cultivar maturity on the composition of newly sown perennial ryegrass (Lolium perenne L.) mixtures. Ir. J. Agric. Food Res. 34:143-150.

Gordon, F. J., C. P. Ferris, D. C. Patterson, and C. S. Mayne. 2000. A comparison of two grassland-based systems for autumn-calving dairy cows of high genetic merit. Grass Forage Sci. 55:83-96.

Greenhalgh, J. F. D., G. W. Reid, and J. N. Aitken. 1967. The effects of grazing intensity on herbage consumption and animal production. The long term effects in strip grazed dairy cows. J. Agric. Sci. (Camb.) 69:217-223.

Hoogendoorn, C. J., C. W. Holmes, and A. C. P. Chu. 1992. Some effects of herbage composition, as influenced by previous grazing management, on milk production by cows grazing on ryegrass/ white clover pastures. 2 . Milk production in late spring/summer: Effects of grazing intensity during the preceding spring period. Grass Forage Sci. 47:316-325.

Horan, B., P. Dillon, P. Faverdin, L. Delaby, F. Buckley, and M. Rath. 2005. The interaction of strain of Holstein-Friesian cows and pasture-based feed systems on milk yield, body weight, and body condition score. J. Dairy Sci. 88:1231-1243.

Horan, B., P. Faverdin, L. Delaby, M. Rath, and P. Dillon. 2006. The effect of strain of Holstein-Friesian dairy cow and pasture-based system on grass intake and milk production. Anim. Sci. 82:435-444.

Kellaway, R., and S. Porta. 1993. Feeding concentrates supplements for dairy cows. Dairy Res. and Dev. Corp., Melbourne, Australia.

Kennedy, E., D. Hennessy, and M. O'Donovan. 2007a. Achieving a 300-day grazing season. Pages 24-28 in Moorepark 07: Irish Dairying-Winning on a World Stage. F. Buckley, ed. Teagasc, Moorepark Dairy Prod. Res. Centre, Fermoy, Co. Cork, Ireland. 
Kennedy, J., P. Dillon, P. Faverdin, L. Delaby, F. Buckley, and M. Rath. 2002. The influence of cow genetic merit for milk production on response to level of concentrate supplementation in a grassbased system. J. Dairy Sci. 75:433-445.

Kennedy, E., M. O’Donovan, J. P. Murphy, L. Delaby, and F. P. O'Mara. 2007b. Effect of spring grazing date and stocking rate on sward characteristics and dairy cow production during midlactation. J. Dairy Sci. 90:2035-2046.

Kennedy, E., M. O'Donovan, J. P. Murphy, and F. O'Mara. 2005. Effects of grass pasture and concentrate-based feeding systems for spring-calving dairy cows in early spring on performance during lactation. Grass Forage Sci. 60:310-318.

Kennedy, E., M. O'Donovan, F. P. O'Mara, J. P. Murphy, and L. Delaby. 2007c. The effect of early-lactation feeding strategy on the lactation performance of spring-calving dairy cows. J. Dairy Sci. 90:3060-3070.

Le Du, Y. L. P., J. Combellas, J. Hodgson, and R. D. Baker. 1979. Herbage intake and milk production by grazing dairy cows. 2 . The effects of level of winter feeding and daily herbage allowance. Grass Forage Sci. 34:249-260.

Lowman, B. G., N. Scott, and S. Somerville. 1976. Condition Scoring of Cattle. Rev. ed. Bull. No. 6. East of Scotland Coll. Agric., Edinburgh, UK.

Maher, J., G. Stakelum, and M. Rath. 2003. Effect of daily herbage allowance on the performance of spring calving dairy cows. Ir. J. Agric. Food Res. 42:229-241.

Mayes, R. W., C. S. Lamb, and P. A. Colgrove. 1986. The use of dosed herbage $\mathrm{n}$-alkanes as markers for the determination of herbage intake. J. Agric. Sci. (Camb.) 107:161-170.

Mayne, C. S., R. D. Newberry, S. C. F. Woodcock, and R. J. Wilkins. 1987. Effect of grazing severity on grass utilisation and milk production of rotationally grazed dairy cows. Grass Forage Sci. 43:137-150.

McEvoy, M., M. O’Donovan, J. P. Murphy, F. O'Mara, T. Boland, and L. Delaby. 2007. Comparison of two techniques to estimate herbage intake of grazing dairy cows. Page 110 in Proc. Agric. Res. Forum 2007. Tullamore, Offaly, Ireland.

Morgan, D. J., G. Stakelum, and J. Dwyer. 1989. Modified neutral detergent cellulose digestibility procedure for use with the "Fibertec" system. Ir. J. Agric. Res. 28:91-92.

O'Donovan, M. 2000. The relationship between the performance of dairy cows and grassland management on intensive dairy farms in Ireland. PhD Thesis. Natl. Univ. of Ireland, Dublin.

O'Donovan, M., L. Delaby, and J. L. Peyraud. 2004. Effect of time of initial grazing date and subsequent stocking rate on pasture production and dairy cow performance. Anim. Res. 53:489-502.
Peyraud, J. L., R. Delagarde, and L. Delaby. 2001. Relationship between milk production, grass dry matter intake and grass digestion. Page 1-19 in Proc. Dairy Conf. Irish Grassl. Assoc., Cork, Ireland. Irish Grassl. Assoc., Ireland.

Roche, J. R. 2007. Milk production responses to pre- and post-calving dry matter intake in grazing dairy cows. Livest. Sci. 110:12-24.

Roche, J. R., P. Dillon, S. Crosse, and M. Rath. 1996. The effect of closing date of pasture in autumn and turnout date in spring on sward characteristics, dry matter yield and milk production of spring-calving dairy cows. Ir. J. Agric. Food Res. 35:127-140.

SAS Institute. 2002. SAS User's Guide: Statistics. SAS Institute Inc., Cary, NC.

Sayers, H. J. 1999. The effect of sward characteristics and level and type of supplement on grazing behaviour, herbage intake and performance of lactating dairy cows. PhD Thesis. Queen's University of Belfast, The Agric. Res. Inst. Northern Ireland. Hillsborough.

Smit, H. J., H. Z. Taweel, B. M. Tas, S. Tamminga, and A. Elgersma. 2005. Comparison of techniques for estimating herbage intake of grazing dairy cows. J. Dairy Sci. 88:1827-1836.

Stakelum, G. 1986. Herbage intake of grazing dairy cows. 2. Effect of herbage allowance, herbage mass and concentrate feeding on the intake of cows grazing primary spring grass. Ir. J. Agric. Res. 25:41-51.

Stakelum, G., and P. Dillon. 1990. Influence of sward structure and digestibility on the intake and performance of lactating and growing cattle. Pages 30-44 in Management Issues for the Grassland Farmer in the 1990's. C. S. Mayne, ed. Br. Grassl. Soc. Occas. Symp., 1990, No. 25. Br. Grassl. Soc., Reading, UK.

Stockdale, C. R. 1999. The nutritive characteristics of herbage consumed by grazing dairy cows affect milk yield responses obtained from concentrate supplementation. Aust. J. Exp. Agric 39:379-387.

Stockdale, C. R. 2000a. Differences in body condition and body size affect the responses of grazing dairy cows to high-energy supplements in early lactation. Aust. J. Exp. Agric. 40:903-911.

Stockdale, C. R. 2000b. Levels of pasture substitution when concentrates are fed to grazing dairy cows in northern Victoria. Aust. J. Exp. Agric. 40:913-921.

Tyrell, H. F., and J. T. Reid. 1965. Prediction of the energy value of cows' milk. J. Dairy Sci. 48:1215-1233.

Urban, B., and J. P. Caudal. 1990. Herbometre automatise (Automatic platemeter). Pages 57-59 in Les Journées de la Mesure. Électronique, Informatique, Automatique. Port Leucate, France. Inst. Natl. Rech. Agron., Paris, France.

Van Soest, P. J. 1963. Use of detergents in the analysis of fibrous feeds. II A rapid method for the determination of fibre and lignin. J. Assoc. Off. Anal. Chem. 46:829-835. 